\title{
Long-Term Care Determinants of Care Arrangements for Older People in Europe: Evidence from SHARE*
}

\author{
VALENTINA HLEBEC * \\ Faculty of Social Sciences \\ University of Ljubljana \\ Ljubljana, Slovenia
}

\section{ANDREJ SRAKAR \\ BORIS MAJCEN}

Institute for Economic Research

Ljubljana, Slovenia

\author{
Original scientific paper \\ UDK: 364.65-053.9 \\ doi: $10.3935 /$ rsp.v26i2.1604 \\ Received: September 2018
}

European countries differ greatly in the proportions of people who receive various types of care. They also differ considerably regarding the societal characteristics of care such as the availability of formal care within the country. We explored the explanatory potential of contextual characteristics of the provision of formal home care, and barriers to using long-term care services for older people's care arrangements across Europe. We employed data from Wave 5 of the Survey of Health, Ageing and Retirement in Europe, and analyze the data using a multinomial logistic model. Less involvement and lower national governance in the integration of home care policy decreases the use of formal care alone, and in combination with informal care. Higher integration and coordination in delivering home-care services increases the use of formal services. In countries with higher shares of reported barriers to using their longterm care systems there is a smaller probability offormal services being used.

Key words: aging in place, informal care, formal care, combined care, care context.

\section{INTRODUCTION}

Organizing care for older people is one of the most important issues in European countries due to the rapidly aging population, and characterized by a rise in the share of the older people caused by longer life expectancy and declining fertility rates. The share of the population aged 80 years and over, which is the most likely to need care, grew from $1.5 \%$ in 1960 to nearly $5 \%$ in 2010 , and is expected to rise to $11 \%$ by

${ }^{*}$ This work was supported by Slovenian Research Agency: Quality of Life of Social Groups [P5-0200 (B)] and Exploring and understanding welfare state determinants of care provision for older people in the community in Slovenia and Austria (J5-8235 (C)).

* Valentina Hlebec, Faculty of Social Sciences / Fakulteta za družbene vede, University of Ljubljana / Univerza v Ljubljani, Kardeljeva ploščad 5, 1000 Ljubljana, Slovenia / Ljubljana, Slovenia, valentina.hlebec@ fdv.uni-lj.si 
2050 and $12 \%$ by 2060 in Europe (Health at a Glance 2013, OECD: 170; The 2015 Ageing Report, European Union: 40). The share of people aged 20-64 will decline substantially from $61 \%$ in 2013 to $51 \%$ by 2060 (ibid.). Thus, we can expect a big increase in the need for care on one hand, and a smaller number of potential informal carers on the other. Both trends are likely to place greater demands on formal care systems across Europe. The purpose of our study is to explore the relationships between the different types and combinations of care old people receive in European countries as well as the social context of care represented by characteristics of long-term systems and organization of home care using Wave 5 SHARE data (Survey of Health Ageing and Retirement in Europe). This will deepen our understanding of how the characteristics of long-term systems, the contextual characteristics of the provision of formal home care, and barriers to using long-term care services influence and shape older people's care arrangements across Europe.

The majority of older people wish to age in place and receive care in their own homes (e.g. Cantor, 1979; Iecovich, 2014). In 2011 , in OECD countries $8.7 \%$ of people aged $65+$ received care in their own homes and only $4.1 \%$ in institutions (Health at a Glance 2013: 181). For people living at home, care can be provided by different parts of informal social networks like family members, friends or neighbours (e.g. Allen, Goldscheider, \& Ciambrone, 1999; Blomgren, Martikainen, Martelin, \& Koskinen, 2008; Cantor, 1979; Wenger, 1994). Care can also be provided by formal care workers such as providers of health and social care or migrant care workers e.g. (e.g. Iecovich, 2010; Shutes \& Chiatti, 2012; Stevens, Hussein, \& Manthorpe, 2012; Walsh \& O'Shea, 2010; Williams, 2012). Further, formal care given to older people living in their own homes can be delivered by public or private providers (e.g. Colombo, Ana,
Jérôme, \& Frits, 2011; Gennet, Boerma, Kroneman, Hutchinson, \& Saltman, 2012). Very often older people combine care from different sources, namely private and public care, formal and informal care, informal care by spouses, children and other informal sources (e.g. Gannon \& Davin, 2010; Litwin \& Attias-Donfut, 2009).

The type of care older people use depends on their preferences and their individual and social contexts (e.g. Andersen \& Newman, 2005). More specifically, some people prefer only informal care (e.g. Cantor, 1979, 1991) and seek care first from their partners and children, then other family members, friends and neighbours. Only in cases where no informal caregivers are available would they accept formal care, provided they can afford it financially and depending on the range of services provided by the community. From this perspective, formal care may be seen as a substitute for informal care (Greene, 1983; Penning, 1995; Pezzin, Kemper, \& Reschovsky, 1996; Penning, 2002). Other older people supplement informal care with formal care when their needs exceed the capacity of informal carers to provide care (Denton, 1997; Edelman \& Hughes, 1990; Stoller \& Pugliesi, 1991). Formal care, therefore, may compensate for a lack of informal care and complement informal care when needs grow (e.g. Chappell \& Blandford, 1991; Denton, 1997). Comparative research also documents the complementary role of formal care in the case of great need and the absence of an informal care network (e.g. Broese Van Groenou, Glaser, Tomassini, \& Jacobs, 2006; Litwin \& Attias-Donfut, 2009; Motel-Klingebiel, Tesch-Roemer, \& Von Kondratowitz, 2005), similarly to single-country studies (e.g. Chappell \& Blandford, 1991; Denton, 1997).

Informal carers provide a vast amount of care to older people in Europe as shown by data from the European Quality of Life Survey (EQLS 2012, own calculations). About $6.4 \%$ (Denmark) to $20.1 \%$ (Lithuania) of the 
adult population in Europe provides care to their older family members or disabled relatives at least once or twice a week. On average, these family members deliver 12.5 hours of care to dependent family members. Care is frequently provided by spouses or children, sometimes also by friends and neighbours (e.g. Cantor, 1979; Stoller \& Pugliesi, 1988; Allen et al., 1999; Barrett \& Lynch, 1999). Most European countries support informal carers with specific policy measures (e.g. Colombo et al., 2011; Mestheneos \& Triantafillou, 2005; Saraceno \& Keck, 2010). Support for informal carers encompasses a variety of services in cash and in kind, services specified for working carers and others (e.g. a carer's allowance, an allowance for the person being cared for, tax credits, additional benefits, paid leave, unpaid leave, flexible work arrangements, training/education, respite care, counselling). Elaborate and abundant support for informal carers increases the likelihood of both informal care and combined informal and formal care, as shown by Suanet et al. (2012).

As we are looking at older people living in their own homes, the provision of public (or private) home care is another crucial dimension of the context of care. Formal care for older people may be delivered by health or social protection systems, it may be included in public and cost-free services delivered through a generous public LongTerm Care (LTC) system, charged according to the means of users, even entirely paid by the users themselves (Colombo et al., 2011; Gennet et al., 2012; Kraus, Czypionka, Riedel, Mot, \& Willemé, 2011). Several studies (e.g. Broese Van Groenou et al., 2006; Litwin \& Attias-Donfut, 2009; Suanet, Van Groenou, et al., 2012) have already revealed differences among European countries regarding the propensity of informal and formal care for people living in their own homes; however, none of these studies has looked closely at how home care is organized in specific countries and whether this significantly influences older people's care arrangements. We suggest that differences in how policymakers balance policy goals and resources in order to provide access and quality formal care in the community across countries and welfare systems (Gennet et al., 2012) may significantly influence the probable nature of older people's care arrangements in these countries. The way in which policymaking evolves and how it is shared between different levels of governance and across different ministries may reflect in cross-country variability in the use of formal services and combining of formal and informal care. In our opinion, better organized formal services, together with a higher degree of integration and coordination, should foster the usage of formal services alone and in combination with informal care in the respective countries.

Apart from support for informal carers, the organization of formal care, the social context of care includes other components. In a broad sense, the social context of older people's care is the welfare system and the social policies with which the state addresses the citizens' needs (Esping-Andersen, 1999). When looking at the welfare context of older people's care, one should observe how much is spent by the state via LTC on institutional care and home-based care, how much is spent by individuals, how generous the pension system is, and how comprehensive the LTC system is (e.g. Bettio \& Plantenga, 2004; Colombo et al., 2011; Kraus et al., 2011; Roostgard, 2002; Saraceno \& Keck, 2010). There are considerable differences in these characteristics across European countries (e.g. Colombo et al., 2011; Gennet et al., 2012; Kraus et al., 2011). At the same time, cross-national studies in Europe (e.g. Bolin, Lindgren, \& Lundborg, 2008; Broese Van Groenou et al., 2006; Motel-Klingebiel et al., 2005; 2015; Suanet, Van Groenou, et al., 2012) 
have revealed substantial differences across European countries relative to the proportions of people receiving various types of care (informal only, formal only and mixed care) and the proportions of people with unmet care needs. Taking both into account, we assume that the LTC characteristics of the welfare context must have a significant influence on the ways older people arrange their care. More specifically, we suppose that in countries where the LTC system is most comprehensive, there is universal access to public services, public services are tailored to needs and not to means, services are delivered via a single system, there should be a greater probability of using formal services or a combination of formal and informal services.

The last indication of how good the formal LTC system actually is at delivering services in specific countries is reflections on barriers reported by users themselves. The quality of services as perceived by those using them can also suggest how the formal LTC system is functioning in providing care to older people in need. We follow the concept of access, addressing several components of access such as availability, accessibility affordability, and quality of services (e.g. Hlebec 2018; Hlebec and Filipovič Hrast 2015; Iecovich \& Carmel, 2009; Kuo \& Torres-Gil, 2001; Penchansky \& Thomas, 1981). We assume that experienced and reported barriers related to availability, accessibility, affordability, and quality of LTC care would be negatively associated with the likelihood of formal care and combined care in specific countries with more barriers reported. More specifically, in countries where the LTC system is expensive, services less available and difficult to access or of lower quality, there would be a lower likelihood of using formal services either alone or in combination with informal care.

The research questions we wish to address in this paper relate to the societal context of care. We assume that the characteristics of particular welfare systems may influence the care arrangements in different societies. More specifically, we would like to explore whether the care-related characteristics of the welfare state context, such as the organization and financing of a long-term care system, organization and provision of home care, and subjective evaluations of the quality of long-term care services have a statistically significant effect on the types of care used by older people in European countries. To summarize, it is expected that in countries with more generous LTC systems, that recognize home care at the policy level (as well as via better organization and coordination of formal home care), the use of formal care alone or in combination with informal care would be more likely. We will use from Wave 5 of SHARE. We will estimate the shares of people (over 65 years old and living in their own home) who receive a specific type of care (no care, only informal care, only formal care, a combination of the two), and test the impact of the societal context of care, which has not yet been explored to such an extent.

\section{RESEARCH DESIGN AND METHODOLOGY}

The data for this study are drawn from the final data version of Wave 5 of SHARE (the Survey of Health, Ageing and Retirement in Europe). This paper uses data from SHARE Wave 5 (10.6103/SHARE. w5.611), see Börsch-Supan et al. (2013) for methodological details. The SHARE data collection has been primarily funded by the European Commission through FP5 (QLK6-CT-2001-00360), FP6 (SHARE-I3: RII-CT-2006-062193, COMPARE: CIT5CT-2005-028857, SHARELIFE: CIT4CT-2006-028812) and FP7 (SHARE-PREP: N²11909, SHARE-LEAP: N²27822, SHARE M4: N²61982). Additional fund- 
ing from the German Ministry of Education and Research, the Max Planck Society for the Advancement of Science, the U.S. National Institute on Aging (U01_AG0974013S2, P01_AG005842, P01_AG08291, P30_AG12815, R21_AG025169, Y1AG-4553-01, IAG_BSR06-11, OGHA_04064, HHSN271201300071C) and from various national funding sources is gratefully acknowledged (see www.share-project.org).

In our analysis, we limited ourselves to respondents aged 65 or older, which limited the final sample to 34,756 respondents. Our sample included all 15 countries participating in Wave 5 of SHARE: Austria, Germany, Sweden, the Netherlands, Spain, Italy, France, Denmark, Switzerland, Belgium, Israel, the Czech Republic, Luxembourg, Slovenia and Estonia, but we excluded Switzerland and Israel due to missing comparative (and reliable) data for the societal characteristics variables.

With regard to the care arrangements, we included both formal and informal care and, concerning the latter, both care within as well as outside the household (also see Bolin et al., 2008; Broese Van Groenou et al., 2006; Litwin \& Attias-Donfut, 2009; Motel-Klingebiel et al., 2005; Suanet, Van Groenou, et al., 2012). Formal care is measured as a dichotomous variable which specifies whether a respondent has received either professional or paid nursing for personal care, domestic tasks, meals-on-wheels or help with other activities, in which case the variable has the value of " 1 ", and " 0 " if a respondent has received none of the above. Informal care is measured as a dichotomous variable, taking a value of " 1 " if a respondent has received either help within (responses to a question asking if there was someone living in the household who had helped him/her regularly during the last 12 months with personal care, such as washing, getting out of bed, or dressing) or outside (responses to a question asking if in the last
12 months any family member from outside the household, any friend or neighbour had provided him/her personal care or practical household help) the household; and " 0 " if a respondent has received neither. For the final variable on care arrangements, the two dichotomous variables for use of informal care and formal care were combined in a measure specifying the type of care arrangement. The four patterns are: 0 "no care use", 1 "only informal care use", 2 "only formal care use", and 3 "a combination of formal and informal care use".

Three types of individual determinants of care arrangements were included in our study, predisposing and enabling factors and need (e.g. Andersen \& Newman, 2005; Bookwala et al., 2004; Broese Van Groenou et al., 2006; Geerlings, Margriet Pot, Twisk, \& Deeg, 2005; Geerts \& Bosch, 2012; Suanet, Van Groenou, et al., 2012). Among the predisposing factors, we included age, gender, and years of education. Living alone and the availability of a child within $25 \mathrm{~km}$ were used as proxy variables for the availability of informal care as an enabling factor. Among the enabling factors, we also included winsorized household income and settlement. Need was measured as functional limitations on a scale from $0-10$ with regard to the number of the following limitations in daily life: walking 100 meters; sitting for about two hours; getting up from a chair after sitting for long periods; climbing several flights of stairs without resting; climbing one flight of stairs without resting; stooping, kneeling, or crouching; reaching or extending your arms above shoulder level; pulling or pushing large objects like a living room chair; lifting or carrying weights over 10 pounds/5 kilos, like a heavy bag of groceries; picking up a small coin from a table. We measured depression as a dichotomous variable, with a value of " 0 " if the score on the EURO-Depression scale (Copeland et al., 1986); was less than 4 and " 1 " if the score was 4 or more. We measured 
chronic illnesses as a dichotomous variable, with a value of " 0 " if a respondent had less than two diseases; and " 1 " if he/she had two or more chronic diseases.

The welfare state context tackles four broad dimensions: financing and public spending on LTC, characteristics of the provision of home care, subjective barriers to use of the LTC system, and support for informal carers (e.g. Colombo et al., 2011; Gennet et al., 2012; Kraus et al., 2011). The data on LTC public expenditure as a share of GDP (OECD Health Statistics 2013) and private household out-of-pocket spending (OECD Health System Accounts Database, 2010) come from different years.

The scope of entitlement for LTC public support can be arranged on a universal vs. means-tested dimension, and whether the coverage is through a single system or multiple services and programs (Colombo et al., 2011, pp. 215, 216-220) (data gathered between 2009 and 2010). Three groups can be identified: 1 - universal coverage within a single program; 2 - mixed systems; and 3 - means-tested safety-net schemes. The third element of comprehensiveness (Colombo et al., 2011, pp. 235-238) evaluates how extensive public LTC protection compared to individual LTC costs is and varies from: 1 - means-tested, defined public contributions, 2- cost sharing as residual, 3 - flat-rate cost sharing, and 4 - income and/or assets-related benefits. The degree of the overall level of national governance in regulating $\mathrm{HC}$ policy was measured in the following way: 1 - municipal, 2 - mixed regional/municipal, 3 - regional or mixed national/municipal, 4 - mixed national / regional, 5 - national. The overall level of national governance in the integration of HC policy was measured in the following way: 1 - two ministries, several schemes, 2 - two ministries, two schemes, 3 - one ministry, more schemes, 4 - one ministry. The strength of organizational integration was measured as (Gennet et al., 2012, pp. 36, 78): 1 - segregated, 2 - partly integrated, 3 - integrated, and the strength of formal coordination (ibid.: 78): 1 - hardly anywhere, 2 - in some areas, 3 - usually. Barriers to the use of formal services from the user's perspective (availability, accessibility, affordability, quality) were evaluated with EQLS (2012, own calculations), asking four questions on either who used the LTC system or would like to have used it in the last 12 months, or who knew about it from someone else in their household or from someone close to them outside the household. The eligible respondents evaluated whether the costs, availability, access, or quality of care made it very difficult to use LTC services.

The dependent variable is categorical and encompasses different types of longterm care. Our categories for the dependent variable are therefore the following:

- Category 0 (reference category) - respondents with no help received;

- Category 1 (informal care only) - respondents receiving any type of informal, but not receiving formal care;

- Category 2 (formal care only) - respondents receiving any type of formal care, but not receiving informal care;

- Category 3 (formal and informal care) respondents receiving a combination of both types of care, formal and informal.

Model-multinomial logistic; predisposing, enabling, need and societal variables:

Age

Gender (0-male, 1-female)

Years of education

Living alone (0-does not live alone, 1-lives alone)

Child living in proximity ( 0 -does not have a child within a range of $25 \mathrm{~km}$, 1-has a child within a range of $25 \mathrm{~km}$ ) 
Household income (EUR, winsorized)

Settlement (0-rural, 1-urban)

Number of functional limitations

Depression (0-scoring less than 4 on Euro-Depression scale; 1 -scoring 4 or more)

Chronic diseases (0-less than 2 diseases, 1-2 or more chronic diseases)

Societal characteristics

A multinomial logistic model was used in a model with four categories, where the reference category was Category 0 (respondents with no long-term care received).

Model:

$$
\begin{gathered}
\log \frac{\operatorname{Pr}\left(Y_{i}=j\right)}{\operatorname{Pr}\left(Y_{i}=0\right)} \\
=a_{j}+b_{1, j} X_{1}+b_{2, j} X_{2}+b_{3, j} X_{3}+b_{4, j} X_{4}+b_{5, j} X_{5} \\
+b_{6, j} X_{6}+b_{7, j} X_{7}+b_{8, j} X_{8}+b_{9, j} X_{9}+b_{10, j} X_{10}+b_{1} \\
X_{11}+b_{12, j} X_{12}+b_{13, j} X_{13}+e_{i, j} \\
j=1,2,3,4
\end{gathered}
$$

$Y i$ - Category of the dependent variable (type of care)

$a-$ Constant

$b i-$ Regression coefficients

$X i$ - Independent variables

e - Error

\section{ANALYSIS OF CROSS- \\ NATIONAL DIFFERENCES OF THE COMPOSITION OF CARE ARRANGEMENTS}

We will first observe how countries differ with respect to the composition of individual and enabling characteristics of care arrangements on a descriptive level. This should give us an insight into the cross-national differences that may influence the occurrence of care arrangements for individuals living in these countries. 


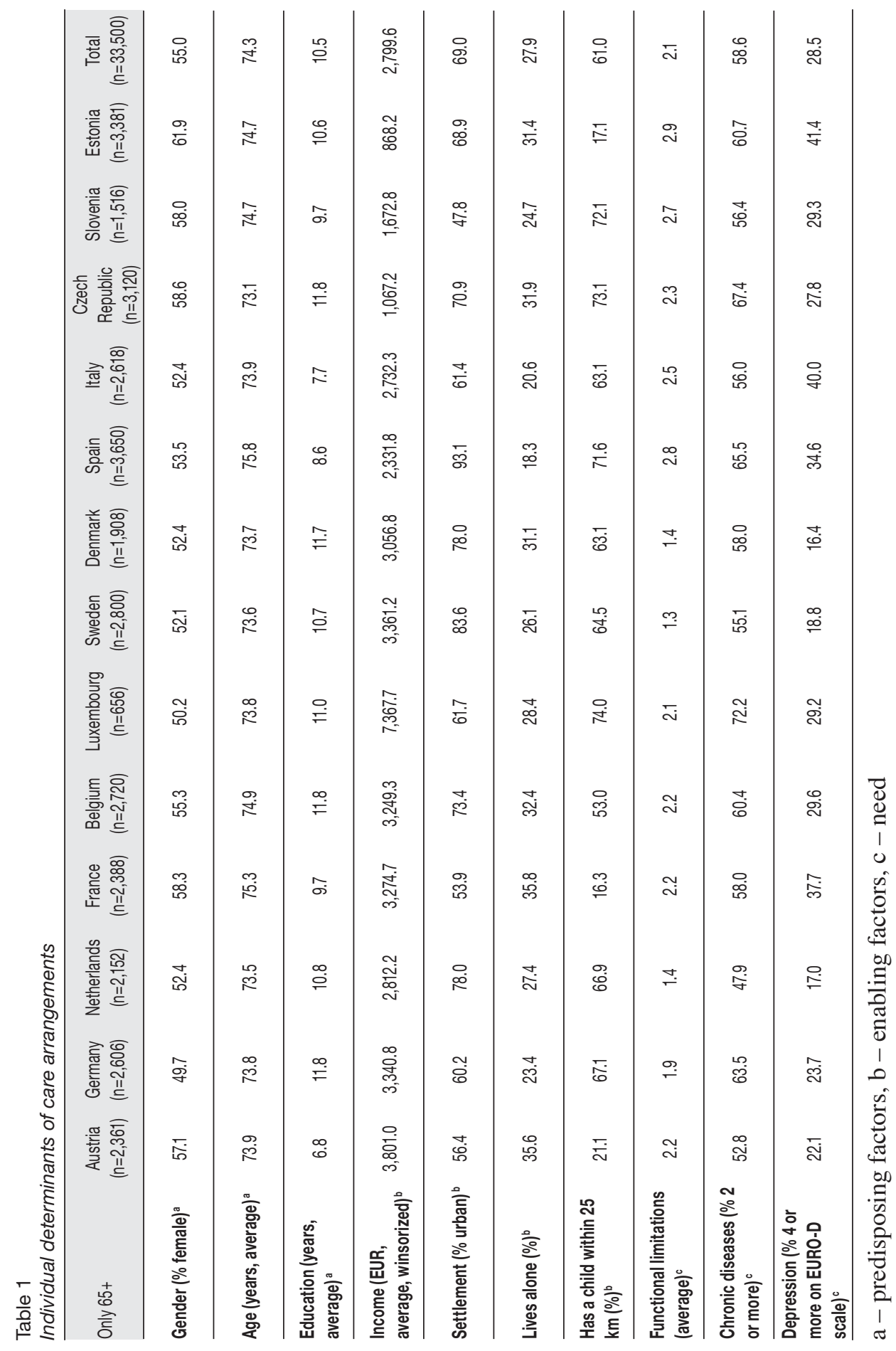


In some respects, the individual determinants of care arrangements across countries (Table 1) differ considerably, such as years of education, household income, percentage of people living in urban settlements, has a child living within $25 \mathrm{~km}$, number of functional limitations, percentage of respondents with two or more chronic diseases or scoring high on the depression scale. In regard to gender composition, namely, the first of the predisposing characteristics, four countries have around $60 \%$ of women in the population aged 65+ (Estonia, Czech Republic, France and Slovenia), while only one has a proportion lower than $50 \%$ (Germany). The average age is quite similar across countries. The average ages of education vary from below 7\% (Austria) to above $11 \%$ (Germany, Belgium, Denmark, and Czech Republic).

In relation to the enabling factors, which mostly influence the use of various forms of care at the individual level, there are larger differences across countries than for the predisposing factors. Respondents in Luxemburg have the highest income on average, about seven times higher than in Eastern European countries. Countries differ considerably with regard to the share of people living in urban areas, varying from 93\% in Spain to $48 \%$ in Slovenia. While only about $20 \%$ of older people live alone in Spain and Italy, about 36\% do so in Austria and France. There are enormous differences across European countries concerning the share of older people with a child who resides within close proximity, less than $20 \%$ in countries such as Estonia, France and Austria, to more than $70 \%$ in countries like Luxembourg, the Czech Republic, Slovenia, and Spain. This may be related to a country's size, but may also be related to the migration of children or older people themselves within and outside the country of residence.

On average, the number of functional limitations, as the first indicator of need, is nearly 3 in Estonia, Slovenia and Spain, only 1.3 in Sweden. The percentage of people having two or more chronic diseases is above $60 \%$ in the Czech Republic, Spain, Germany, Estonia, and Belgium, and below $50 \%$ in the Netherlands. The highest scores on the depression scale are for older people living in Estonia, Italy and France (about $40 \%$ ), while the lowest scores are for those in Sweden, the Netherlands, and Denmark (below 18\%). 


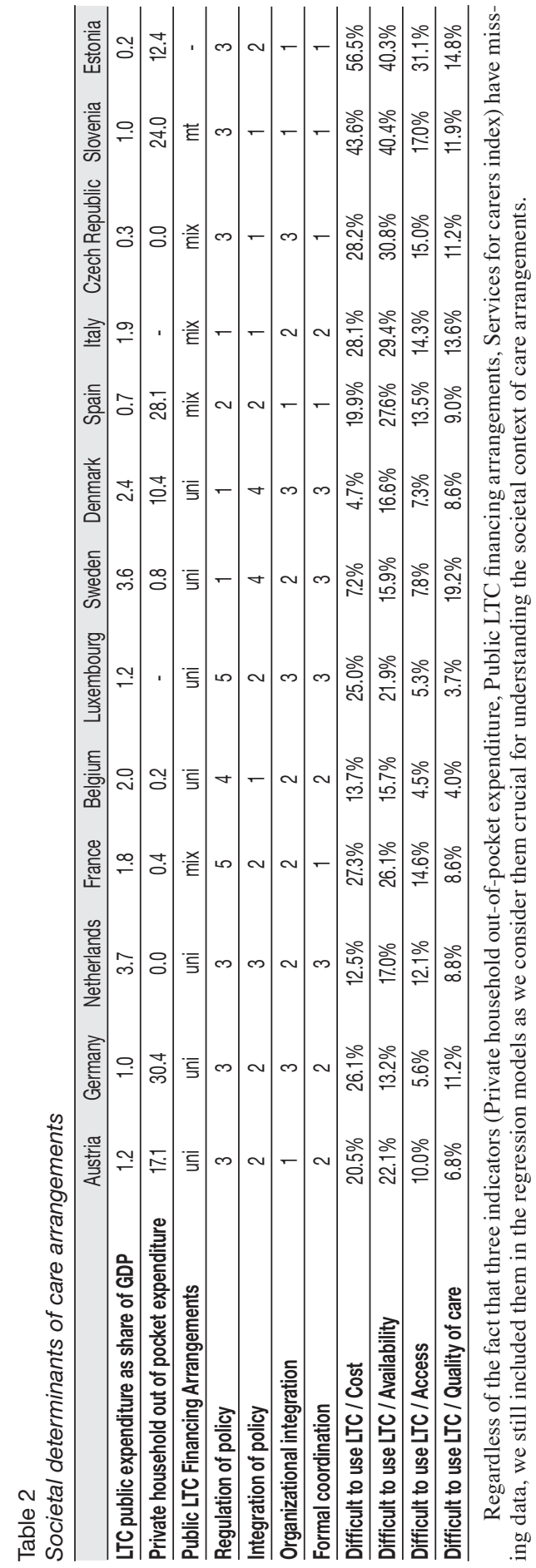

As regards the societal context of care patterns (Table 2), there are also considerable differences across countries. The public expenditure of GDP for the LTC system varies from 0.2 (Estonia) up to 3.7 in the Netherlands. Private, out-of-pocket expenditure varies from 0 (Czech Republic and the Netherlands) to $30 \%$ (Germany). Public LTC financing arrangements are means-tested in Slovenia. The regulation of formal home care policy occurs at the national level in France and Luxembourg and at the municipal level in Sweden, Denmark, and Italy. The overall level of national governance in the integration of home care policy is strongest in Sweden and Denmark, and lowest in Belgium, Italy, the Czech Republic, and Slovenia. Austria, Spain, Slovenia, and Estonia have weak organizational integration of home care, while in Germany, Luxembourg, Denmark, and the Czech Republic it is strong. Formal coordination of home care is strong in the Netherlands, Luxembourg, Sweden, and Denmark, and weak in France, Spain, the Czech Republic, Slovenia, and Estonia. By far the biggest shares of respondents reporting barriers to use of the formal LTC system due to issues of affordability are reported in Estonia and Slovenia (56.5\% and $43.6 \%$, respectively). The same is true for barriers arising from the availability of formal LTC services (40\% in Slovenia and Estonia), followed by the Czech Republic, Italy, Spain, and France (all around 30\%). Without doubt, the highest share of respondents reporting barriers to use of the formal LTC system due to the accessibility of services is reported in Estonia $(31.1 \%)$, followed by Slovenia, the Czech Republic, Italy, Spain, and France (around $15 \%$ ). Barriers stemming from service quality are reported by the highest share of respondents in Sweden (19\%). 
Table 3

Cross-country differences in the distribution of care arrangements

\begin{tabular}{lcccc}
\hline & no care & only informal care & only formal care & combination \\
\hline Austria & $69.08 \%(1631)$ & $13.85 \%(327)$ & $6.90 \%(163)$ & $10.17 \%(240)$ \\
\hline Germany & $73.87 \%(1925)$ & $12.24 \%(319)$ & $5.22 \%(136)$ & $8.67 \%(226)$ \\
\hline Netherlands & $72.63 \%(1563)$ & $8.27 \%(178)$ & $12.31 \%(265)$ & $6.78 \%(146)$ \\
\hline France & $68.97 \%(1647)$ & $9.42 \%(225)$ & $11.64 \%(278)$ & $9.97 \%(238)$ \\
\hline Belgium & $62.06 \%(1688)$ & $10.18 \%(277)$ & $15.81 \%(430)$ & $11.95 \%(325)$ \\
\hline Luxembourg & $69.51 \%(456)$ & $10.52 \%(69)$ & $10.37 \%(68)$ & $9.60 \%(63)$ \\
\hline Sweden & $79.50 \%(2226)$ & $10.14 \%(284)$ & $5.61 \%(157)$ & $4.75 \%(133)$ \\
\hline Denmark & $68.82 \%(1313)$ & $15.04 \%(287)$ & $7.18 \%(137)$ & $8.96 \%(171)$ \\
\hline Spain & $71.26 \%(2601)$ & $14.33 \%(523)$ & $7.26 \%(265)$ & $7.15 \%(261)$ \\
\hline Italy & $74.56 \%(1952)$ & $15.81 \%(414)$ & $5.12 \%(134)$ & $4.51 \%(118)$ \\
\hline Czech Republic & $60.93 \%(1901)$ & $27.92 \%(871)$ & $3.33 \%(104)$ & $7.82 \%(244)$ \\
\hline Slovenia & $81.60 \%(1237)$ & $13.92 \%(211)$ & $1.65 \%(25)$ & $2.84 \%(43)$ \\
\hline Estonia & $66.84 \%(2260)$ & $19.28 \%(652)$ & $3.05 \%(103)$ & $10.83 \%(366)$ \\
\hline Total & $70.46 \%(24490)$ & $14.24 \%(4948)$ & $7.17 \%(2491)$ & $8.13 \%(2827)$ \\
\hline
\end{tabular}

There are obviously large cross-country variations (Table 3) in proportions of "no care", informal care only, formal care only, and combined informal and formal care. There are countries where nearly one-third of the population aged $65+$ receives only informal care (Czech Republic) and others where only $8 \%-10 \%$ receives informal care (the Netherlands, France, Belgium, Luxembourg, and Sweden). In some countries, exclusively formal care is quite rare (less than 3.3\%), such as Slovenia, Estonia, and the Czech Republic - all Eastern European countries. The percentage of combining informal and formal care is the lowest in Slovenia (2.8\%) and the highest in Belgium (12\%). 
Table 4

Individual and societal determinants of care arrangements in 13 European countries (main effects model, multinomial logit)

\begin{tabular}{|c|c|c|c|}
\hline & only informal & only formal & combination \\
\hline & B & B & $\mathrm{B}$ \\
\hline Constant & $-5.374^{\star \star \star}$ & $-11.046^{\star \star \star}$ & $-11.830^{* \star *}$ \\
\hline Gender & 0.064 & $0.257^{\star \star \star}$ & $0.103^{*}$ \\
\hline Age & $0.031^{\star \star \star}$ & $0.104^{\star \star \star}$ & $0.099^{\star \star *}$ \\
\hline Years of education & $0.028^{\star * \star}$ & $0.039^{* \star *}$ & $0.040^{* \star *}$ \\
\hline Income & $-0.000^{\star \star \star}$ & $0.000^{\star \star}$ & 0.000 \\
\hline Settlement & $-0.181^{\star \star *}$ & 0.055 & -0.074 \\
\hline Living alone & $0.882^{\star \star \star}$ & $0.759^{\star \star \star}$ & $1.078^{\star \star \star}$ \\
\hline Child living in proximity & $0.176^{\star \star \star}$ & $-0.172^{\star \star \star}$ & 0.005 \\
\hline Functional limitations & $0.245^{\star \star \star}$ & $0.267^{\star \star \star}$ & $0.459^{\star \star \star}$ \\
\hline Number of chronic diseases & $0.188^{\star \star \star}$ & $0.208^{\star \star \star}$ & $0.561^{\star \star *}$ \\
\hline Depression & $0.367^{\star \star \star}$ & $0.369^{\star \star \star}$ & $0.474^{\star \star \star}$ \\
\hline LTC public expenditure as share of GDP & $-0.166^{\star \star \star}$ & $0.383^{\star \star \star}$ & $0.150^{\star \star \star}$ \\
\hline Private household out-of-pocket expenditure & $-0.010^{\star \star \star}$ & $-0.032^{\star \star \star}$ & $-0.021^{\star \star \star}$ \\
\hline $\begin{array}{l}\text { Public LTC Financing Arrangements in OECD countries } \\
\text { - MT/UNI }\end{array}$ & $-0.625^{\star \star \star}$ & $-3.093^{\star \star \star}$ & $-2.116^{\star \star \star}$ \\
\hline $\begin{array}{l}\text { Public LTC Financing Arrangements in OECD countries } \\
\text { - MIX/UNI }\end{array}$ & $0.100^{\star \star}$ & $-0.541^{\star \star \star}$ & $-0.723^{\star \star *}$ \\
\hline Regulation of policy & $-0.055^{\star \star \star}$ & $0.226^{\star \star \star}$ & $0.170^{\star \star *}$ \\
\hline Integration of policy & $-0.063^{\star \star \star}$ & $0.063^{\star \star}$ & $0.149^{\star \star \star}$ \\
\hline Organizational integration & $0.249^{\star \star \star}$ & $0.206^{\star \star \star}$ & $0.289^{* \star *}$ \\
\hline Formal coordination & $-0.086^{\star \star \star}$ & $0.413^{\star \star \star}$ & $0.315^{\star \star \star}$ \\
\hline Difficult to use LTC / Cost & 0.001 & $-0.038^{\star \star \star}$ & $-0.015^{\star \star \star}$ \\
\hline Difficult to use LTC / Availability & $0.008^{\star \star \star}$ & $-0.061^{\star \star \star}$ & $-0.037^{* \star *}$ \\
\hline Difficult to use LTC / Access & $0.005^{\star}$ & $-0.066^{\star \star \star}$ & $-0.029^{\star \star \star}$ \\
\hline Difficult to use LTC / Quality of care & $0.014^{\star * *}$ & $-0.133^{\star \star \star}$ & $-0.073^{* \star *}$ \\
\hline PseudoR-squared & 0.178 & & \\
\hline WaldChi2 & 8.432 .536 & & \\
\hline LogLikelihood & -19.437 .42 & & \\
\hline $\mathrm{N}$ & 25.929 & & \\
\hline
\end{tabular}

${ }^{*} p<0.10,{ }^{* *} p<0.05,{ }^{* * *} p<0.01$

The coefficients of an individual's characteristics and variance intercept refer to those estimated for the model incorporating the "co-reside" societal characteristic. "No care" is the reference category. We used multinomial logistic multi-level analyses to evaluate how much the differences in societal characteristics explain cross-na- tional patterns of informal and formal care use. Given the small number of countries included in the analyses, we modelled each societal characteristic in separate models. There are significant variations across countries with respect to the four patterns of care (no care, informal care only, formal care only, combination of informal and 
formal care), namely, PseudoR-squared = 0.178, WaldChi2 = 8432.536 $(\mathrm{p}=0.000)$, LogLikelihood $=-19437.42, \mathrm{~N}=25929$. We tested the models for the independence of irrelevance alternatives (IIA) assumption using the Hausman and Small-Hsiao tests, as well as against combining and collapsing alternatives using the Wald and LR tests. No problems in any of the models were detected in the testing.

As in other studies, the care patterns are determined by individual characteristics (Andersen \& Newman, 2005; Bookwala et al., 2004; Geerlings et al., 2005; Geerts \& Bosch, 2012; Suanet, van Groenou, \& Van Tilburg, 2012).

In countries with higher public LTC spending and higher private LTC spending the likelihood of receiving only informal care is significantly lower. Having mixed public financial arrangements, as opposed to universal public funding, significantly increases informal care only, while having means-tested public financial arrangements decreases the likelihood of having informal care only. It seems that generous LTC financing reduces informal care, but so does higher private spending. In countries with more generous LTC public spending as a share of GDP and more generous pensions, there is a significantly higher likelihood of having formal care only, and combined care. As expected, in countries with higher out-of-pocket expenditure on LTC, there is a significantly lower likelihood of formal care only, and combined care. Both mixed and means-tested public LTC financing arrangements, as opposed to universal public LTC financial arrangements, significantly reduce the likelihood of using formal care only, and combined care. The effect is much stronger for means-tested arrangements than for mixed arrangements.

In countries with a higher level of policy regulation and integration of formal care as well as with a higher level of formally orga- nized $\mathrm{CH}$ home care, informal care only is significantly less likely. On the other hand, a higher level of organizational integration is positively related to informal care only. The strength of involvement of policymaking in the area of $\mathrm{HC}$, the overall level of national governance in integration of HC policy, the level of organizational integration and formal coordination within the $\mathrm{HC}$ system all seem to increase the likelihood of formal only and combined care across countries.

As expected, in countries with a bigger share of people experiencing barriers when using the formal LTC system, the likelihood of informal care only is higher. As expected, in countries where there is a higher percentage of people reporting barriers to the use of formal services (availability, accessibility, affordability, quality) there is a lower probability of formal care only, and combined care.

\section{DISCUSSION}

Several methodological issues should be outlined and specified. The time lag between the year of collecting the micro data (2013) and the other data, especially for the societal determinants of care arrangements, is considerable for some indicators, regardless of our efforts to provide the most recent data possible. As stated by Colombo et al. (2011), the majority of European countries have made significant changes in policy measures regarding their LTC systems, and this may reflect in contradictory effects for some societal characteristics. Further, the three indicators of societal characteristics (private household out-of-pocket expenditure, public LTC financing arrangements, and services for carers indices) have missing data, despite the goal of making the data sources as comprehensive as possible. We nevertheless included them in the regression models as we consider them very important for understanding the societal context of care arrangements. 
Regardless of the methodological limitations, our findings corroborate a number of previous studies (e.g. Bookwala et al., 2004; Broese Van Groenou et al., 2006; Geerlings et al., 2005; Geerts \& Bosch, 2012; Litwin \& Attias-Donfut, 2009; Suanet, van Groenou, et al., 2012). The individual components of the care usage, need, and availability of informal carers as an enabling factor strongly influence the use of any kind of care.

The characteristics of LTC systems (Colombo et al., 2011), specific contextual characteristics of home care (Gennet et al., 2012), and subjective evaluations of the quality of long term care services (EQLS 2012) were tested as social determinants of care arrangements. We have shown that they are important for explaining variability in older people's care arrangements across European countries. The effect of these components is stronger on the usage of formal care and combined care than on the usage of informal care.

As expected, in countries with more generously arranged LTC systems (where little payment is expected, services are delivered via a single system, home care is recognized and integrated at the policy level) the use of formal care alone or in combination with informal care is more likely. Combining formal and informal care may be more important in the future as retirement ages across Europe increase. In countries with fragmented long-term systems, awareness of the variety of services available to older people or their informal carers may a cause of the smaller use of formal services. On the other hand, the delivery of services via one integrated system may improve the efficiency of service delivery, prevent a cross-section of services within separate health and social services, and reduce the costs of care.

The actual organization of formal home care (Gennet et al., 2012) has an effect on use of formal care alone and in combination with informal care. The effect of the organizational contextual characteristics of home care on the usage of formal home care has been shown in a few national studies (e.g. Demaerschalk, Boer, Bronselaer, Molenberghs, \& Declercq, 2013; 2014), but has not yet been tested in a cross-national study. As expected, a higher degree of integration and coordination promotes the use of formal services alone and in combination with informal care. We have shown that the fragmentation of this part of the long-term system is related to the low usage of formal services. It may be that with increasing demand for services owing to the aging population, pressure to make the service delivery system more efficient and more coordinated will grow.

The accessibility of formal services (Hlebec 2018; Hlebec and Filipovič Hrast 2015; e.g. Lecovich \& Carmel, 2009; Kuo \& Torres-Gil, 2001; Penchansky \& Thomas, 1981) has a significant effect on the use of these services across countries. In fact, user perceptions of barriers to access to the formal long-term system are indicative of the lower use of formal services, either alone or in combination with informal care. A lower quality formal care system in terms of higher costs, lower availability, limited access, and a lower quality of services negatively influences the use of such services across countries.

It is very difficult to determine whether the cultural norms or the absence of integrated, universally accessible, and a generous long-term system entailing the coordinated delivery of formal services to older people in their homes reduces the use of formal services alone or in combination with informal care in countries with a poorly developed LTC system. Decisions about different types of care are usually made in complex individual, family, community, and country contexts and may be better understood via in-depth qualitative inquiries 
taking everything into account at the same time. Further, the SHARE data will enable longitudinal observations to be made concerning changes in the care arrangements of individuals, at least for a limited number of countries. This should give us further insights into how decisions about care are shaped by different LTC systems.

\section{CONCLUSIONS}

Apart from the needs and individual characteristics of older people, the social context of care determines the use of different types of care, such as informal care, formal care and combined care for people aging in place. It is obvious, from our study, that not only broad, welfare and care regimes characteristics, but also mezzo level characteristics, have significant impacts on care arrangements. The actual organization of formal home care (Gennet et al., 2012) has an effect on use of formal care alone and in combination with informal care. The effect of the organizational contextual characteristics of home care on the usage of formal home care has been shown in a few national studies (e.g. Demaerschalk, Boer, Bronselaer, Molenberghs, \& Declercq, 2013; 2014), but now we have evidence of its affects in a cross-national study. These, mezzo level characteristics of organization of care for older people should be studied closely in the future.

\section{REFERENCES}

Allen, S. M., Goldscheider, F., \& Ciambrone, D. A. (1999). Gender roles, marital intimacy, and nomination of spouse as primary caregiver. The Gerontologist, 39(2), 150-158. https://doi. org/10.1093/geront/39.2.150

Andersen, R., \& Newman, J. F. (2005). Societal and individual determinants of medical care utilization in the United States. The Milbank Quarterly, 83(4), 95-124. https://doi.org/10.1111/j.14680009.2005.00428.x

Barrett, A. E., \& Lynch, S. M. (1999). Caregiving networks of elderly persons: Variation by marital status. The Gerontologist, 39(6), 695-704. https:// doi.org/10.1093/geront/39.6.695

Bettio, F., \& Plantenga, J. (2004). Comparing care regimes in Europe. Feminist Economics, 10(1), 85-113. https://doi. org/10.1080/1354570042000198245

Blomgren, J., Martikainen, P., Martelin, T., \& Koskinen, S. (2008). Determinants of home-based formal help in community-dwelling older people in Finland. European Journal of Ageing, 5(4), 335347. https://doi.org/10.1007/s10433-008-0094-4

Bolin, K., Lindgren, B., \& Lundborg, P. (2008). Informal and formal care among single-living elderly in Europe. Health Economics, 17(3), 393-409. https://doi.org/10.1002/hec.1275

Bookwala, J., Zdaniuk, B., Burton, L., Lind, B., Jackson, S., \& Schulz, R. (2004). Concurrent and long-term predictors of older adults' use of community-based long-term care services: The caregiver health effects study. Journal of Aging and Health, 16(1), 88-115. https://doi. org/10.1177/0898264303260448

Börsch-Supan, A., M. Brandt, C. Hunkler, T. Kneip, J. Korbmacher, F. Malter, B. Schaan, S. Stuck, \& S. Zuber (2013). Data Resource Profile: The survey of health, ageing and retirement in Europe (SHARE). International Journal of Epidemiology, 42(4), 992-1001. https://doi.org/10.1093/ ije/dyt088

Broese Van Groenou, M., Glaser, K., Tomassini, C., \& Jacobs, T. (2006). Socio-economic status differences in older people's use of informal and formal help: A comparison of four European countries. Ageing \& Society, 26(5), 745-766. https:// doi.org/10.1017/S0144686X06005241

Cantor, M. H. (1979). Neighbors and friends: An overlooked resource in the informal support system. Research on Aging, 1(4), 434-463. https://doi. org/10.1177/016402757914002

Cantor, M. H. (1991). Family and community: Changing roles in an aging society. The Gerontologist, 31(3), 337-346. https://doi.org/10.1093/ geront/31.3.337

Chappell, N., \& Blandford, A. (1991). Informal and formal care: Exploring the complementarity. Ageing and Society, 11(3), 299-317. https://doi. org/10.1017/S0144686X00004189

Colombo, F., Ana, L.-N., Jérôme, M., \& Frits, T. (2011). OECD Health Policy Studies help wanted? Providing and paying for long-term care. Paris: OECD Publishing.

Demaerschalk, M. F., Boer, L. E. V., Bronselaer, J. L., Molenberghs, G., \& Declercq, A. G. (2013). 
The influence of municipal characteristics on the use of informal home care and home care services by the elderly Flemish. The European Journal of Public Health, 23(2), 241-246. https:// doi.org/10.1093/eurpub/cks068

Denton, M. (1997). The linkages between informal and formal care of the elderly. Canadian Journal on Aging, 16(1), 30-50. https://doi.org/10.1017/ S0714980800014148

Edelman, P., \& Hughes, S. (1990). The impact of community care on provision of informal care to homebound elderly persons. Journal of Gerontology, 45(2), S74-S84. https://doi.org/10.1093/ geronj/45.2.S74

Esping-Andersen, G. (1999). Social foundations of postindustrial economies. Oxford: Oxford University Press.

Gannon, B., \& Davin, B. (2010). Use of formal and informal care services among older people in Ireland and France. The European Journal of Health Economics, 11(5), 499-511. https://doi. org/10.1007/s10198-010-0247-1

Geerlings, S. W., Margriet Pot, A., Twisk, J. W. R., \& Deeg, D. J. H. (2005). Predicting transitions in the use of informal and professional care by older adults. Ageing and Society, 25(1), 111-130. https://doi.org/10.1017/S0144686X04002740

Geerts, J., \& Bosch, K. V. den. (2012). Transitions in formal and informal care utilisation amongst older Europeans: the impact of national contexts. European Journal of Ageing, 9(1), 27-37. https:// doi.org/10.1007/s10433-011-0199-z

Gennet, N., Boerma, W., Kroneman, M., Hutchinson, A., \& Saltman, R. (2012). Home care across Europe: Current structure and future challenges. The European Observatory on Health Systems and Policies supports. Available at http://www. euro.who.int/en/publications/abstracts/homecare-across-europe.-current-structure-and-future-challenges-2012

Greene, V. L. (1983). Substitution between formally and informally provided care for the impaired elderly in the community. Medical Care, 21(6), 609-619. https://doi.org/10.1097/00005650198306000-00003

Hlebec, V. (2014). Individual and contextual determinants of social homecare usage in Slovenia (Dispozicijski in kontekstualni dejavniki uporabe socialne oskrbe na domu). Slovenian Journal of Public Health, 53(4), 311-317. https://doi. org/10.2478/sjph-2014-0034

Hlebec, V. (2018). Evaluation of access to long-term care services for old people ageing in place in Slovenia. Slovenian journal of public health,
57(3), 116-123. https://doi.org/10.2478/sjph2018-0015

Hlebec V., \& Filipovič Hrast, M. (2015). Ovrednotenje dostopa do socialne oskrbe na domu z vidika uporabnikov. Teorija in Praksa, 52(1-2), 48-66. Available at https://repozitorij.uni-lj.si/ IzpisGradiva.php?id=85389

Iecovich, E. (2010). Tasks performed by primary caregivers and migrant live-in homecare workers in Israel. International Journal of Ageing \& Later Life, 5(2), 53-75. https://doi.org/10.3384/ ijal.1652-8670.105253

Iecovich, E. (2014). Aging in place: From theory to practice. Anthropological Notebooks, 20(1), 21-33. Available at http://www.drustvo-antropologov.si/AN/PDF/2014_1/Anthropological_ Notebooks_XX_1_Iecovich.pdf

Iecovich, E., \& Carmel, S. (2009). Differences in accessibility, affordability, and availability (AAA) of medical specialists among three agegroups of elderly people in Israel. Journal of Aging and Health, 21(5), 776-797. https://doi. org/10.1177/0898264309333322

Kraus, M., Czypionka, T., Riedel, M., Mot, E., \& Willemé, P. (2011). How European Nations care for their elderly: A new typology of longterm care systems. SSRN Scholarly Paper No. 2005018. Available at http://papers.ssrn.com/ abstract $=2005018$

Kuo, T., \& Torres-Gil, F. M. (2001). Factors affecting utilization of health services and home-and community-based care programs by older Taiwanese in the United States. Research on Aging, 23(1), 14-36. https://doi.org/10.1177/0164027501231002

Litwin, H., \& Attias-Donfut, C. (2009). The inter-relationship between formal and informal care: a study in France and Israel. Ageing \& Society, 29(1), 71-91. https://doi.org/10.1017/ S0144686X08007666

Mestheneos, E., \& Triantafillou, J. (2005). Supporting family carers of older people in Europe: The Pan-European Background Report (Vol. 1). Münster: LIT Verlag.

Motel-Klingebiel, A., Tesch-Roemer, C., \& Von Kondratowitz, H.-J. (2005). Welfare states do not crowd out the family: Evidence for mixed responsibility from comparative analyses. Ageing \& Society, 25(6), 863-882. https://doi.org/10.1017/ S0144686X05003971

Penchansky, R., \& Thomas, J. W. (1981). The concept of access: Definition and relationship to consumer satisfaction. Medical Care, 19(2), 127-140. https://doi.org/10.1097/00005650198102000-00001 
Penning, M. J. (1995). Health, social support, and the utilization of health services among older adults. The Journals of Gerontology Series B: Psychological Sciences and Social Sciences, 50B(5), S330-S339. https://doi.org/10.1093/ geronb/50B.5.S330

Penning, M. J. (2002). Hydra revisited substituting formal for self-and informal in-home care among older adults with disabilities. The Gerontologist, 42(1), 4-16. https://doi.org/10.1093/geront/42.1.4

Pezzin, L. E., Kemper, P., \& Reschovsky, J. (1996). Does publicly provided home care substitute for family care? Experimental evidence with endogenous living arrangements. The Journal of Human Resources, 31(3), 650-676. https://doi. org $/ 10.2307 / 146270$

Roostgard, T. (2002). Caring for children and older people in Europe: A comparison of European policies and practice. Policy Studies, 23(1), 51-68. https://doi.org/10.1080/0144287022000000082

Saraceno, C., \& Keck, W. (2010). Can we identify intergenerational policy regimes in Europe? European Societies, 12(5), 675-696. https://doi. org/10.1080/14616696.2010.483006

Shutes, I., \& Chiatti, C. (2012). Migrant labour and the marketisation of care for older people: The employment of migrant care workers by families and service providers. Journal of European Social Policy, 22(4), 392-405. https://doi. org/10.1177/0958928712449773

Srakar, A., Filipovič Hrast, M., Hlebec, V., \& Majcen, B. (2015). Social exclusion, welfare regime and unmet long-term care need: Evidence from SHARE. In A. Börsch-Supan, T. Kneip, H. Litwin, M. Myck \& G. Weber (Eds.), Ageing in Europe - Supporting Policies for an Inclusive Society (pp. 189-198). Berlin: De Gruyter. https:// doi.org/10.1515/9783110444414-019
Stevens, M., Hussein, S., \& Manthorpe, J. (2012). Experiences of racism and discrimination among migrant care workers in England: Findings from a mixed-methods research project. Ethnic and Racial Studies, 35(2), 259-280. https://doi.org/1 $0.1080 / 01419870.2011 .574714$

Stoller, E. P., \& Pugliesi, K. L. (1988). Informal networks of community-based elderly changes in composition over time. Research on Aging, 10(4), 499-516. https://doi. org/10.1177/0164027588104004

Stoller, E. P., \& Pugliesi, K. L. (1991). Size and effectiveness of informal helping networks: A panel study of older people in the community. Journal of Health and Social Behavior, 32(2), 180-191. https://doi.org/10.2307/2137151

Suanet, B., Van Groenou, M. B., \& Van Tilburg, T. (2012). Informal and formal home-care use among older adults in Europe: Can cross-national differences be explained by societal context and composition?. Ageing \& Society, 32(3), 491-515. https://doi.org/10.1017/S0144686X11000390

Walsh, K., \& O'Shea, E. (2010). The role of migrant care workers in ageing societies: Report on research findings in the United Kingdom, Ireland, Canada and the United States (Report). International Organization for Migration IOM Migration Research Series No. 41. Available at https:// aran.library.nuigalway.ie/handle/10379/3217

Wenger, G. C. (1994). Support networks of older people: A guide for practitioners. Bangor: Centre for Social Policy Research \& Development, University of Wales.

Williams, F. (2012). Converging variations in migrant care work in Europe. Journal of European Social Policy, 22(4), 363-376. http://doi. org/10.1177/0958928712449771 


\title{
Sažetak \\ ODREDNICE DUGOROČNE SKRBI U ORGANIZACIJI SKRBI ZA STARIJE OSOBE U EUROPI: DOKAZI IZ ISTRAŽIVANJA O ZDRAVLJU, STARENJU I UMIROVLJENJU U EUROPI (SHARE)
}

\author{
Valentina Hlebec \\ Fakultet za društvene znanosti, Sveučilište u Ljubljani, Ljubljana, Slovenija \\ Andrej Srakar, Boris Majcen \\ Institut za ekonomska istraživanja, Ljubljana, Slovenija
}

\begin{abstract}
Europske se zemlje znatno razlikuju prema omjerima osoba koje su primatelji različitih vrsta skrbi. Isto tako, znatno se razlikuju u pogledu društvenih značajki skrbi, kao što su dostupnost formalne skrbi unutar zemlje. Istražili smo potencijalna obrazloženja kontekstualnih značajki pružanja formalne kućne skrbi, kao i prepreke korištenju dugoročnih usluga skrbi u organizaciji skrbi za starije osobe diljem Europe. Koristili smo podatke iz. petog vala Istraživanja o zdravlju, starenju i umirovljenju u Europi i analizirali ih uz pomoć multinomijalnog logističkog modela. Manja uključenost i niže nacionalno upravljanje integracije mjera kućne skrbi umanjuje korištenje formalne skrbi, kao i kombinaciju s neformalnim tipovima skrbi. Veća integracija i koordinacija u pružanju usluga kućne skrbi povećava korištenje formalnih usluga. U zemljama s većim udjelom dokumentiranih prepreka za korištenje dugoročnih sustava skrbi postoji manja vjerojatnost korištenja formalnih usluga.
\end{abstract}

Ključne riječi: starenje uz mogućnost dobivanja usluga u vlastitom domu, neformalna skrb, formalna skrb, kombinirana skrb, kontekst skrbi. 